\title{
Deteksi Jumlah dan Pengenalan Wajah Manusia Menggunakan Metode Histogram of Oriented Gradient dan Viola Jones
}

\author{
Human Face Recognition and Amount Detection using Histogram of Oriented Gradient \\ and Viola Jones
}

Feni Budi Antono ${ }^{1}$ Faqih Rofii ${ }^{2}$ Istiadi $^{3}$

${ }^{1,2,3}$ Fakultas Teknik, Universitas Widyagama Malang

e-mail: ${ }^{1}$ bdsambe@gmail.com, ${ }^{2}$ faqih@widyagama.ac.id, ${ }^{3}$ istiadi@widyagama.ac.id

\begin{abstract}
Abstrak
Tingkat kejahatan di lingkungan rumah saat ini semakin meningkat. Ada dua kelemahan manusia yang dimanfaatkan pencuri, yaitu sikap individualisme dan letak rumah yang sulit terjangkau oleh pengawasan keamanan. Solusi yang dilakukan adalah memperkerjakan jasa keamanan untuk menjaga rumah. Pilihan tersebut kurang efesien bagi pemukiman menengah ke bawah. Solusi lain yang banyak digunakan adalah sistem keamanan rumah berbasis CCTV. Kelemahan pada sistem yang aktif terus menerus sehingga membutuhkan penyimpanan data yang cukup besar. Kekurangan dari CCTV tersebut dapat dicover dengan menambahkan fiturfitur teknologi yang akan menambah presentase velue pada waktu yang digunakan. Penelitian ini dilakukan untuk mengetahui bagaimana penerapan fitur-fitur teknologi tersebut pada nilai akurasi serta error yang dihasilkan pada kamera USB. Metode yang digunakan dalam penelitian ini adalah Histogram Of Oriented Gradient sebagai pendeteksi jumlah manusia dan metode Viola Jones sebagai pendeteksi pengenalan wajah. Hasil dari penelitian ini adalah kemampuan maksimal kamera dalam mendeteksi jumlah manusia didapat pada jarak 5-11 meter antara kamera dengan obyek manusia dengan tingkat nilai error yang lebih rendah dari nilai akurat. Sedangkan pada pengenalan wajah jarak optimal yang didapat adalah 1-3 meter antara kamera dengan wajah yang menghasilkan tingkat nilai error lebih tinggi dari nilai akurat dalam mengenali wajah.
\end{abstract}

Kata kunci: Histogram Of Oriented Gradient, Viola Jones, Deteksi Obyek, Deteksi Wajah

\begin{abstract}
Current crime rates in the neighborhood are increasing. There are two human weaknesses that are used by thieves, namely the attitude of individualism and the location of houses that are difficult to reach by security supervision. The solution is to employ security services to protect the house. This choice is less efficient for middle to lower settlements. Another solution that is widely used is CCTV-based home security systems. Weaknesses in the system are continuously active so that it requires considerable data storage. The shortcomings of CCTV can be covered by adding technological features that will increase the velue percentage at the time used. This research was conducted to determine how the application of these technological features to the value of accuracy and errors produced on USB cameras. The method used in this study is Histogram Of Oriented Gradient as a detector for the number of humans and the Viola Jones method as a detection of facial recognition. The results of this study are the maximum ability of the camera to detect the number of humans obtained at a distance of 5-11 meters between the camera and human objects with an error value that is lower than the accurate value. Whereas in the face recognition the optimal distance obtained is 1-3 meters between the camera and the face which results in a higher level of error value than the accurate value in recognizing faces.
\end{abstract}

Keyword: Histogram of Oriented Gradient, Viola Jones, Object Recognition, Face Recognition 


\section{PENDAHULUAN}

Tingkat kejahatan di lingkungan rumah saat ini semakin meningkat. Ada dua faktor kelemahan manusia yang selalu dimanfaatkan pencuri pertama sikap individualisme dan kedua letak rumah yang sulit terjangkau oleh pengawasan keamanan.. Banyak modus yang dilakukan para pencuri untuk melaksanakan aksinya mulai dari berpura-pura menjadi pemilik rumah dan merusak jendela bahkan ada yang merusak dinding rumah dengan tujuan untuk masuk ke rumah yang menjadi target. Rumah kosong tersebut menjadi sasaran empuk bagi para pencuri, terutama rumah tanpa sistem keamanan yang memadai.Solusi yang banyak digunakan adalah sistem keamanan rumah berbasis CCTV (Closed Circuit Televison)[1] yang pada umumnya sistem pemantauan ini masih dilakukan dengan cara manual oleh manusia dengan menggunakan kamera $C C T V$ untuk merekam kejadian di tempat yang dianggap rawan oleh penghuni rumah selama 24 jam penuh setiap harinya, hal tersebut jelas kurang efektif dan harus dalam pengawasan penghuni rumah melalui monitor. Kekurangan dari CCTV tersebut dapat dicover dengan menambahkan fitur-fitur teknologi yang mana akan mengisi jumlah presentase velue pada waktu yang digunakan. Dalam artian sekali melakukan rekaman, CCTV kita melakukan dua hingga tiga pekerjaan. Hal ini sudah pasti menjadikan kerja CCTV lebih efektif serta efesien.

Beberapa penelitian terkait deteksi gerak telah dilakukan dengan penggunan metode background subtraction dengan algoritma Gaussian Mixture Model [2]. Tetapi metode tersebut memiliki kelemahan dimana obyek yang memiliki warna yang sama dengan background dianggap sama, sehingga walaupun obyek tersebut bergerak tidak dianggap sebagai pergerakan. Penggunaan metode background subtraction dengan algoritma gaussian mixture model [2]. Memiliki rata-rata akurasi hasil deteksi manusia pada kondisi dalam ruangan adalah $86,1 \%$, sedangkan pada kondisi luar ruangan adalah $88,3 \%$. Sudut orientasi posisi manusia terhadap kamera yang paling baik adalah pada sudut $0^{\circ}, 45^{\circ}$, dan $90^{\circ}$

Metode Histogram of Oriented Gradient merupakan metode feature based yang melihat tampilan lokal dan bentuk obyek pada citra berupa intensitas distribusi gradient atau arah kontur dengan alasan bahwa postur orang yang dideteksi memiliki variasi penampilan [3]. Metode HOG memberikan fleksibilitas yang lebih daripada metode lain, karena metode ini berdasarkan feature ekstraksi yang digunakan pada komputer vision dan pengolahan citra dengan cara menghitung nilai gradien pada suatu citra untuk mendapatkan hasil yang akan digunakan untuk mendeteksi obyek [4]. Metode ini menggunakan database berupa histogram yang berisi kumpulan nilai gradient pada sebaran orientasi tertentu. Citra yang diperoleh kamera diubah menjadi grayscale kemudian dinormalisasikan kecerahannya serta melalui proses koreksi gamma [5].

Penggunaan metode HOG Cascade [6]. Dimana jarak obyek terhadap kamera sangat berpengaruh terhadap hasil pendeteksian manusia akan terdeteksi oleh kamera jika minimal 2/3 bagian obyek harus tertangkap oleh kamera. Sedangkan metode Viola Jones merupakan gabungan empat kunci utama yaitu Haar Like Feature, Integral Image, Adaboost learning dan Cascade classifier [7] sehingga memiliki akurasi yang cukup tinggi. Tingkat keakuratan yaitu sekitar 93,7 \% dengan kecepatan 15 kali lebih cepat dari pada detektor Rowley Baluja-Kanade dan kurang lebih 600 kali lebih cepat daripada detektor Schneiderman-Kanade. Metode ini, diusulkan oleh Paul Viola dan Michael Jones pada tahun 2001 [8].

Prosedur deteksi Viola-Jones mengklasifikasikan gambar berdasarkan pada nilai fitur sederhana. Alasan yang paling umum adalah bahwa fitur dapat digunakan untuk mengkodekan pengetahuan domain ad-hoc yang sulit dalam pembelajaran terhadap data yang terbatas jumlahnya. Alasan penting untuk menggunakan fitur adalah sistem fitur berbasis operasi jauh lebih cepat daripada sistem berbasis piksel [9]. Fitur yang digunakan oleh Viola dan Jones didasarkan pada Wavelet Haar. Karakteristik dari algoritma Viola-Jones adalah adanya klasifikasi bertingkat. Klasifikasi pada algoritma ini terdiri dari tiga tingkatan dimana tiap tingkatan mengeluarkan subcitra yang diyakini bukan wajah [10]. 
Metode $H O G$ menghasilkan penerapan teknologi pemrosesan video yang mampu mendeteksi jumlah manusia sedangkan metode Viola-Jones yang mampu menguatkan dan mensingkronkan sistem kerja metode sebelumnya, memiliki fungsi pendeteksian tiap-tiap wajah manusia yang terekam oleh kamera CCTV. Masukan sistem dari kedua metode diatas harapannya dapat mempermudah manusia dalam menggunakan kamera $C C T V$ secara efektif dan efisien. Jika kedua metode di atas diaplikasikan maka kinerja dari CCTV akan bertambah, dimana selain merekam dapat juga menghitung jumlah obyek manusia dan mendeteksi wajah manusia secara individu. Melihat dari manfaat yang didapat serta hasil yang mampu menyelesaikan masalah keamanan dan efektifitas CCTV.

\section{METODE PENELITIAN}

Dalam penelitian ini, diusulkan proses utama yaitu proses deteksi jumlah dan pengenalan wajah manusia menggunakan metode Histogram of Oriented Gradient dan Viola Jones

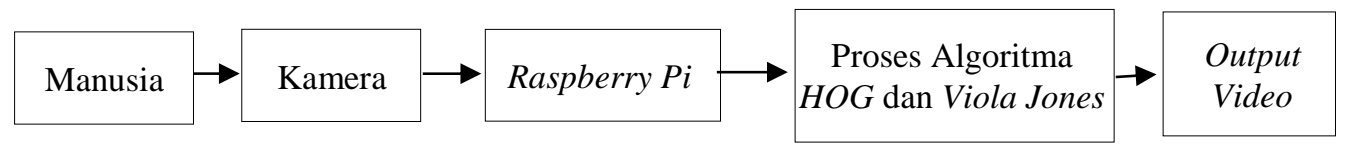

Gambar 1 Blok Diagram Sistem Deteksi Jumlah dan Pengenalan Wajah Manusia

Gambar 1 menunjukkan proses dimulai dari obyek manusia sebagai input citra dalam bentuk video (diambil menggunakan kamera). Kemudian video akan diproses oleh raspberry setelah diproses oleh raspberry maka akan digunakan metode Histogram of Oriented Gradien dan Viola Jones kemudian output video berfungsi untuk memberikan informasi hasil sistem deteksi. Sebelum melakukan deteksi pengenalan wajah akan dilakukan proses training classifier menggunakan sampel citra dari obyek. Sampel terdiri dari 20 citra wajah. Setelah itu, classifier yang dihasilkan dari proses training ini digunakan untuk proses deteksi obyek. Adapun tahapan lebih jelas dari penelitian akan dijelaskan sebagai berikut:

\section{A. Pembuatan Dataset}

Pemodelan sistem membutuhkan sejumlah dataset pelatihan sehingga sistem dapat mengidentifikasi wajah tertentu dan fitur umum yang terkait dengan obyek. Berikut adalah sampel dataset berupa 20 citra wajah dengan sudut wajah yang berbeda-beda:

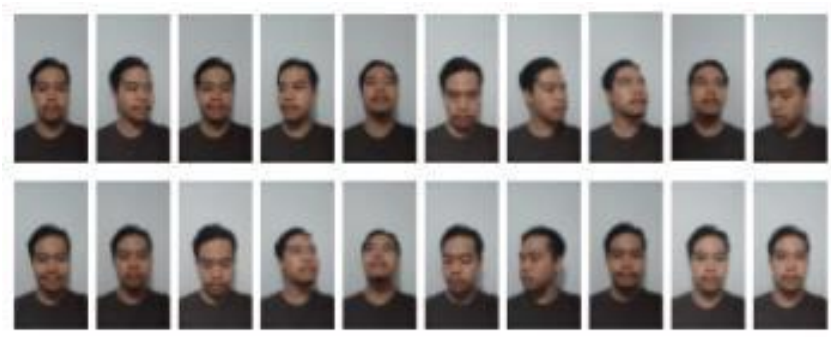

Gambar 2 Citra Wajah Dataset

Untuk mengkonversi sebuah citra wajah dengan klasifikasi Local Binary Patterns (LBP) digunakan matrik 3 x 3 dari matrik tersebut akan dipindai seluruh piksel bagian wajah melintasi satu gambar. Pada setiap gerakannya dilakukan perbandingan piksel di tengah dengan piksel sekitarnya. Nyatakan piksel sekitar dengan nilai intensitas kurang dari atau sama dengan piksel tengah maka nilai sama dengan 0 dan jika lebih besar dari nilai piksel tengah maka nilai sama dengan 1. Setelah mendapatkan nilai-nilai $0 / 1$ dengan matrik $3 \times 3$ dalam urutan searah jarum jam, maka akan didapatkan pola biner 11100011 pada area tertentu dari gambar. Jika pada seluruh gambar sudah dipindai, maka akan mucul daftar Local Binary Patterns (LBP) setelah didapatkan daftar Local Binary Patterns (LBP), akan dikonversikan masing-masing menjadi angka desimal menggunakan konversi biner ke decimal 


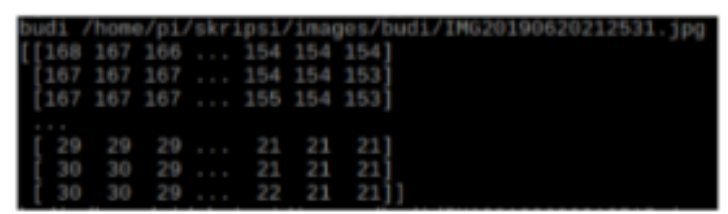

Gambar 3 Histogram Citra Dataset

Jika ada 20 gambar dalam dataset pelatihan maka $L B P H$ akan mengekstraksi 20 histogram. setelah pelatihan akan disimpan untuk klasifikasi wajah. Algoritma ini juga akan membedakan histogram dari setiap wajah yang berbeda antara orang satu dengan orang lainnya. Bahan dan alat apa saja yang akan digunakan dalam pembuatan sistem deteksi pengenalan wajah dan deteksi jumlah manusia, di antaranya meliputi:

1. Raspberry Pi 3 Model B.

2. Adaptor Raspberry Pi.

3. Camera USB (Universal Serial Bus)

4. Laptop

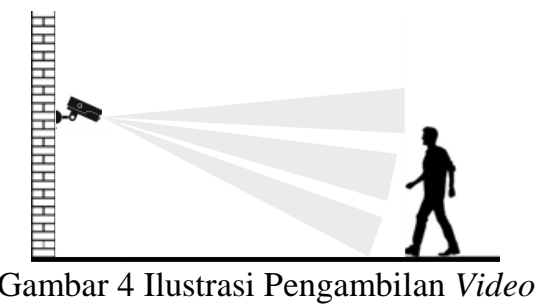

Ilustrasi pengambilan gambar ditunjukan seperti pada gambar 2 pada ilustrasi tersebut posisi kamera diletakan dengan ketinggian $150 \mathrm{~cm}$.

A. Deteksi Jumlah Manusia

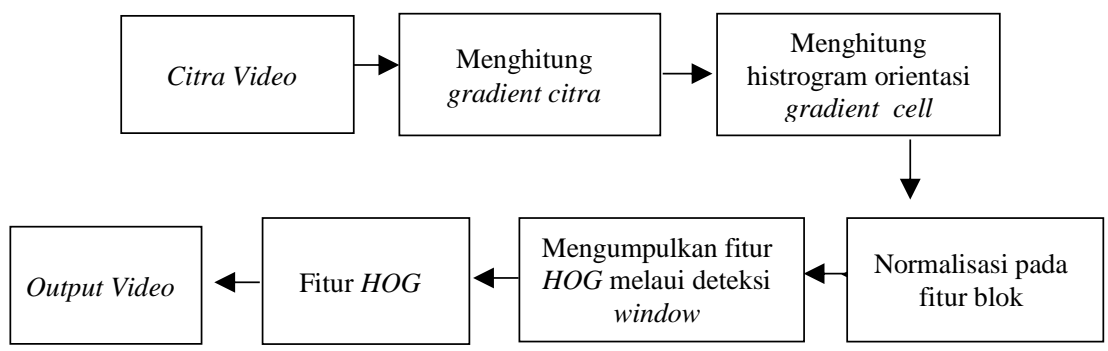

Gambar 5 Proses Algoritma Histogram of Oriented Gradient

Dari Gambar 4 tahap awal dari metode $H O G$ adalah menghitung nilai gradient citra dihitung menggunakan;

$|G|=\sqrt{I x^{2}+I y^{2}}$

Dimana $I$ adalah citra graylevel. Ix merupakan matrik terhadap sumbu- $x$ dan $I y$ merupakan matrik terhadap sumbu-y. Ix dan Iy dapat dihitung dengan;

$I x=I * D x, I y=I * D y(2)$

D $x$ adalah mask $\left[\begin{array}{lll}-1 & 0 & 1\end{array}\right]$, sedangkan Dy adalah mask $\left[\begin{array}{c}-1 \\ 0 \\ 1\end{array}\right]$ masing masing dihitung dengan cara konvolusi. Kemudian gradient ditransformasi ke $\left[\begin{array}{l}0 \\ 1\end{array}\right]$ dalam kordinat sumbu dengan sudut diantara 0 sampai 1800 yang disebut orientasi gradient. Orientasi gradient $(\theta)$ dapat dihitung dengan 
$\theta=\arctan \left(\frac{1 x}{1 y}\right)$

Tahap selanjutnya adalah melakukan perhitungan histogram dari orientasi gradient tiap cell. Setiap piksel dalam sebuah cell mempunyai nilai histogram sendiri-sendiri berdasarkan nilai yang dihasilkan dalam perhitungan gradient yang kemudian dilakukan normalisasi pada setiap blok. Cell memiliki ukuran $8 \times 8$ piksel pada sebuah citra. Sedangkan blok memiliki ukuran $2 \times 2$ cell. Nilai normalisasi fitur blok didapat dari Fitur blok dinormalisasi untuk mengurangi efek perubahan kecerahan obyek pada satu blok. Variabel b merupakan nilai blok fitur dan variabel e merupakan bilangan positif yang bernilai kecil untuk mencegah pembagian dengan 0 .

$b=\frac{b}{b^{2}+e}$

Nilai normalisasi tiap blok digabungkan menjadi satu vektor menjadi fitur vektor HOG. Kemudian fitur vektor $H O G$ dilakukan normalisasi melalui (4). Variabel $h$ merupakan nilai fitur $H O G$ dan variabel $e$ merupakan bilangan positif yang bernilai kecil untuk mencegah pembagian dengan 0 .

$h=\frac{h}{\sqrt{\|h\|^{2}+e}}$

B. Deteksi Wajah

Pada proses deteksi wajah menggunakan metode Haar Cascade Classifier, terdapat beberapa proses untuk mendapatkan output wajah yang terdeteksi. Proses tersebut yaitu HaarLike Featrure, Integral image, Adaboost (Adaptive Boosting), dan Cascade Classifier. Proses dari setiap tahap dalam deteksi kendaraan ditunjukkan pada Gambar

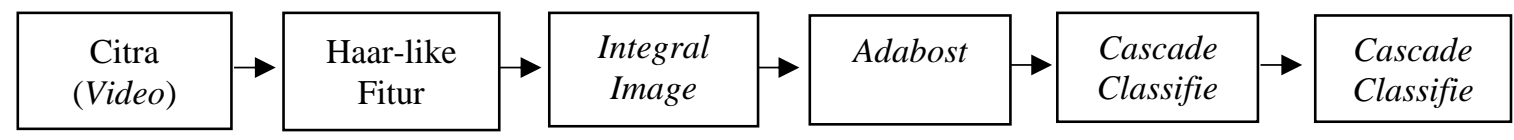

Gambar 6 Proses deteksi Haar Cascade Classifier

\section{Fitur Haar}

Fitur ini terdiri dari satu nilai interval tinggi dan satu nilai interval rendah untuk gambar dua dimensi disebut sebagai daerah terang dan daerah gelap. Fitur ini memiliki kelebihan berupa kinerja komputasinya yang sangat cepat

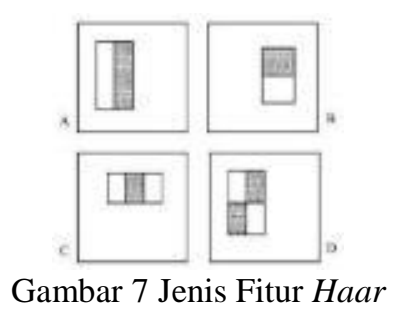

Fitur pada bagian (A) dan (B) terdiri dari dua persegi panjang, bagian (D) terdiri dari 4 (empat) persegi panjang, dan bagian (C) terdiri dari tiga persegi panjang. Setiap fitur menghasilkan suatu nilai tunggal dan cara menghitung nilai fitur adalah dengan mengurangkan nilai piksel pada daerah terang dengan nilai piksel pada daerah gelap. Kotak rectangular HaarLike Feature dapat dihitung secara cepat dengan menggunakan Integral Image. Lalu untuk gambar bergerak (video), perhitungan dan penjumlahan pixel terjadi secara terus menerus dan membutuhkan waktu yang lama. Hasil deteksi dari Haar-Like kurang akurat jika hanya menggunakan satu fungsi saja sehingga biasanya digunakan beberapa fungsi sekaligus. Semakin banyak fungsi yang digunakan maka hasilnya akan semakin akurat. 


\section{Integral Image}

Integral Image adalah sebuah citra yang nilai tiap pikselnya merupakan penjumlahan dari nilai piksel kiri atas hingga kanan bawah. Untuk memudahkan proses perhitungan nilai dari setiap Fitur Haar pada setiap lokasi gambar digunakan teknik yang disebut citra integral. Secara umum integral mempunyai makna menambahkan bobot, bobot merupakan nilai-nilai piksel yang akan ditambahkan ke dalam gambar asli. Nilai integral dari setiap piksel merupakan jumlah dari semua piksel sebelah atasnya dan di sebelah kirinya. Keseluruhan gambar dapat diintegrasikan dengan operasi bilangan bulat per piksel.

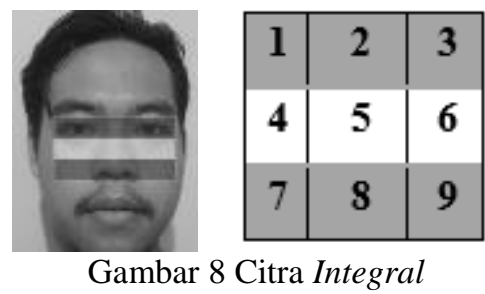

\section{Adaptive Boosting}

AdaBoost menggabungkan banyak classifier lemah untuk membuat sebuah classifier kuat. Lemah disini berarti urutan filter pada classifier hanya mendapatkan jawaban benar lebih sedikit. Jika keseluruhan classifier lemah digabungkan maka akan menjadi classifier yang lebih kuat. AdaBoost memilih sejumlah classifier lemah untuk disatukan dan menambahkan bobot pada setiap classifier, sehingga akan menjadi classifier yang kuat.

Viola-Jones menggabungkan beberapa AdaBoost classifier sebagai rangkaian filter yang cukup efisien untuk menggolongkan daerah image. Masing-masing filter adalah satu AdaBoost Classifier terpisah yang terdiri classifier lemah atau satu filter Classifier lemah tersebut menetapkan suatu bobot sehingga apabila digabungkan akan menjadi satu classifier yang kuat. Untuk memaksimalkan performa AdaBoost dalam sistem, Viola Jones menyarankan metode brute force yaitu, menentukan classifier lemah dengan cara mengevaluasi setiap fitur pada semua data training untuk menemukan fitur dengan kinerja terbaik. Namun hal ini diduga menjadi penyebab lamanya prosedur.

4. Cascade Classifier

Klasifikasi pada algoritma ini terdiri dari tiga tingkatan dimana tiap tingkatan mengeluarkan subcitra yang diyakini bukan wajah. Hal ini dilakukan karena lebih mudah untuk menilai subcitra tersebut bukan wajah ketimbang menilai apakah subcitra tersebut berisi wajah.

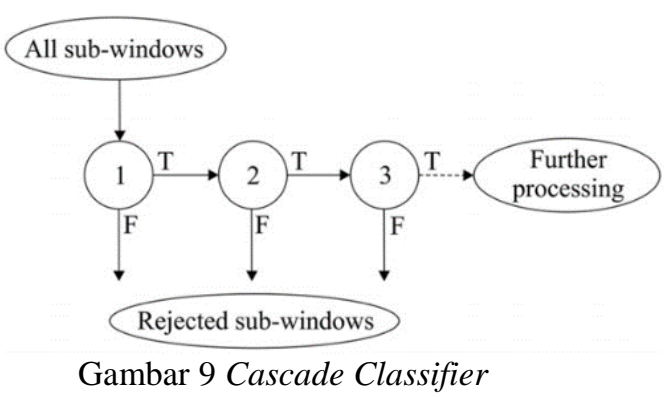

Pada klasifikasi tingkat pertama, tiap subcitra akan diklasifikasi menggunakan satu fitur. Hasil dari klasifikasi pertama ini berupa T (True) untuk gambar yang memenuhi fitur Haar tertentu dan $\mathrm{F}$ (False) bila tidak. Klasifikasi ini akan menyisakan 50\% subcitra untuk diklasifikasi di tahap kedua. Hasil dari klasifikasi kedua berupa T (True) untuk gambar yang memenuhi proses integral image dan $\mathrm{F}$ (False) bila tidak. 


\section{HASIL DAN PEMBAHASAN}

A. Deteksi Jumlah Manusia

Untuk megetahui tingkat akurasi sistem deteksi jumlah manusia meggunakan metode Histogram of Oriented Gradient $(H O G)$ akan dilakukan tiga macam pengujian yang pertama. untuk mengetahui jarak minimun dan maksimum jangkauan deteksi Jumlah manusia.

Tabel 1 Deteksi Jarak Antara Kamera dengan Manusia

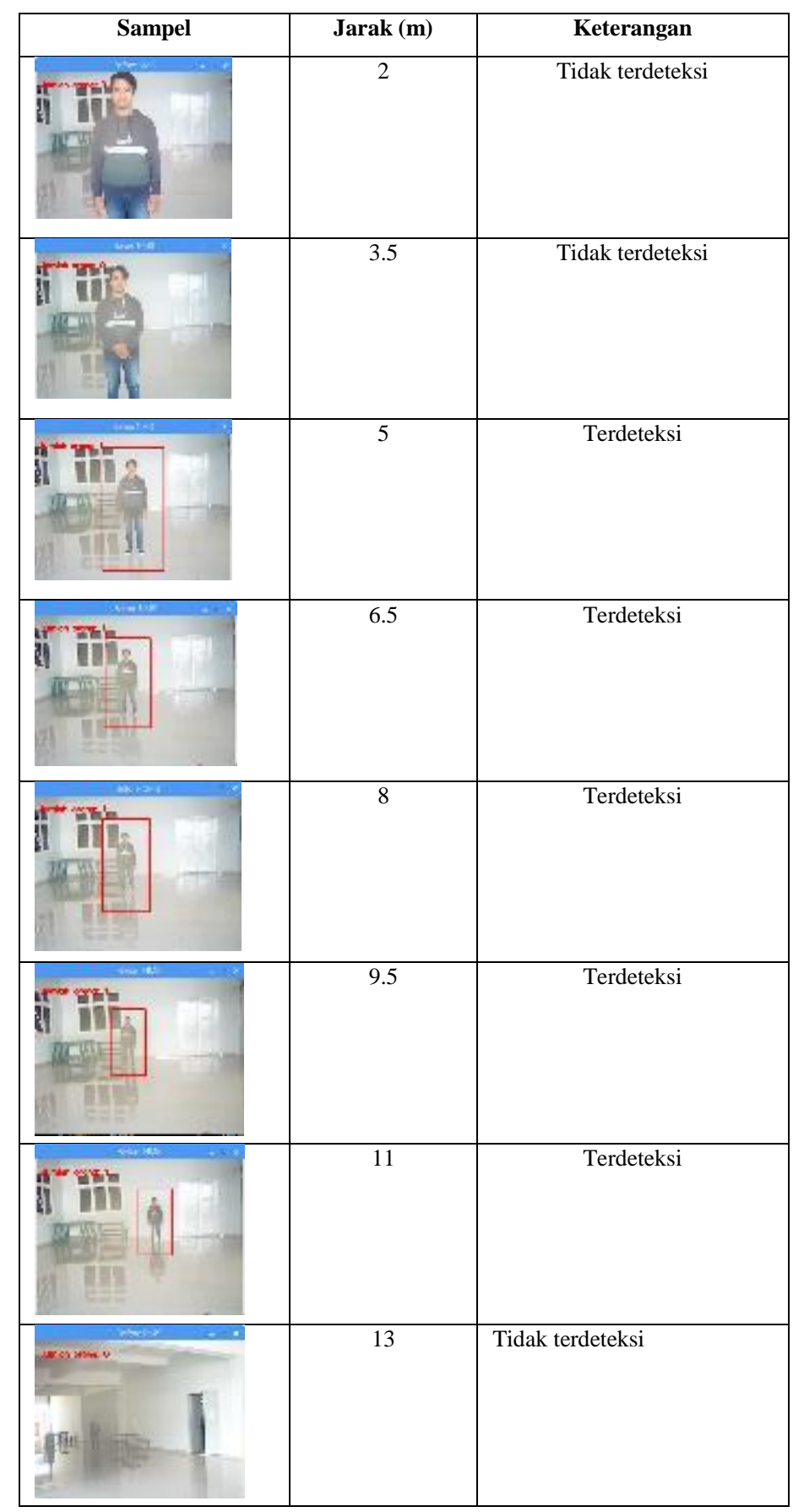

Pengujian kedua adalah deteksi jumlah manusia. Pengujian ini dilakukan untuk mengetahui tingkat akurasi jumlah manusia terdeteksi. Pengujian dilakukan dengan sampel 1 sampai 10 manusia pada jarak 6 meter. 
Techno.COM, Vol. 19, No.1, Februari 2020: 12-23

Tabel 2 Hasil dari Pengujian Jumlah Manusia Terdeteksi

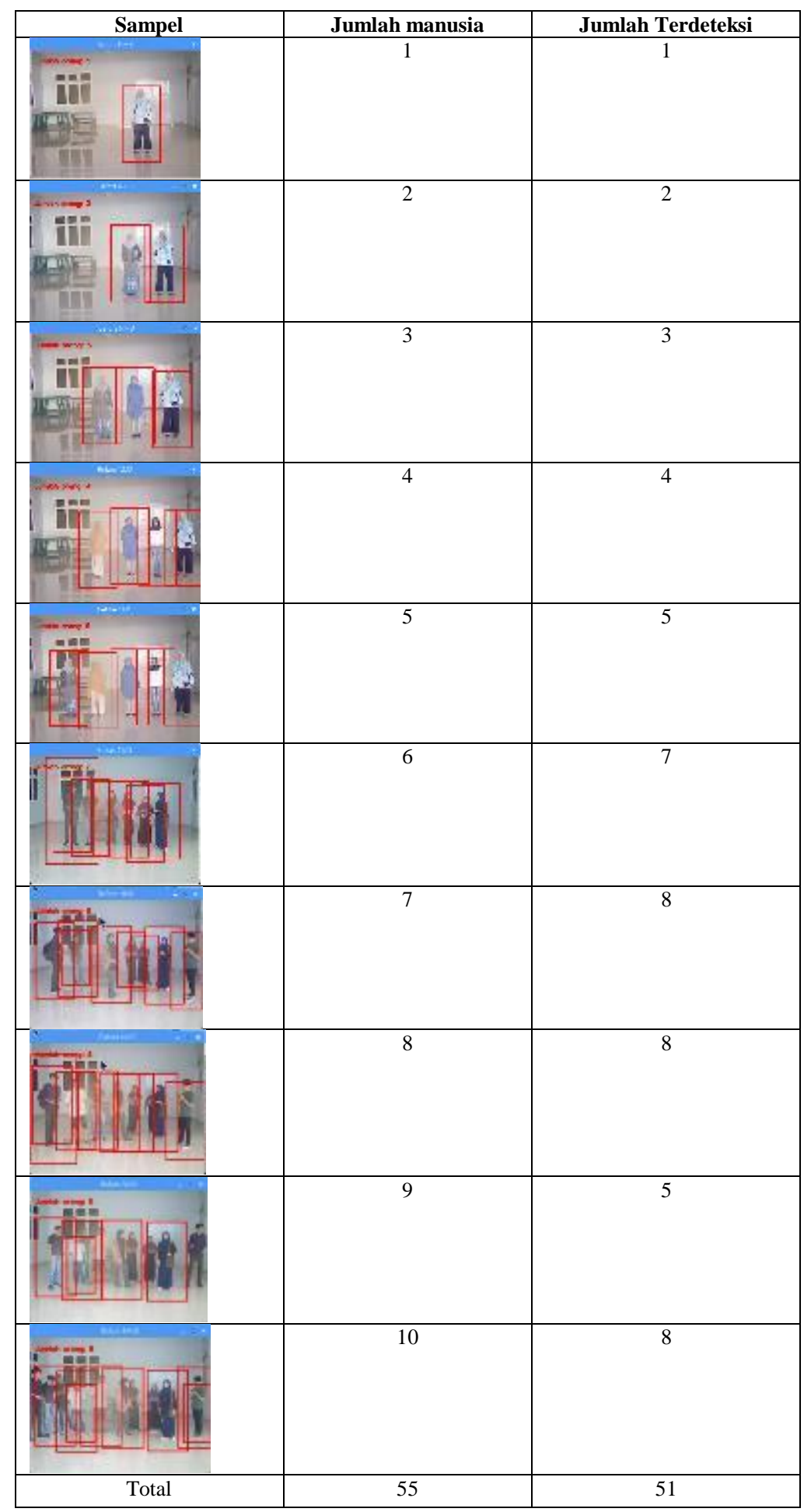

Pengujian ketiga adalah jarak antara manusia, bertujuan untuk mengetahui pendeteksian dengan orang yang bersebelahan. dalam pengujian ini diambil sampel 2 obyek manusia dengan jarak 4 meter, 7 meter dan 11 meter dengan kerapatan antar manusia mulai dari dua obyek yang membelakangi obyek manusia bergeser sampai dengan jarak maksimal $50 \mathrm{~cm}$.

B. Deteksi Pengenalan Wajah 
Untuk megetahui tingkat akurasi sistem pengenalan wajah dilakukan dua macam percobaan yang pertama pengujian deteksi jarak antara kamera dengan wajah. Pengujian ini dilakukan untuk mengetahui jarak minimun dan maksimum jangkauan deteksi pengenalan wajah.

Tabel 3 Hasil Deteksi Jarak antara Kamera dengan Wajah

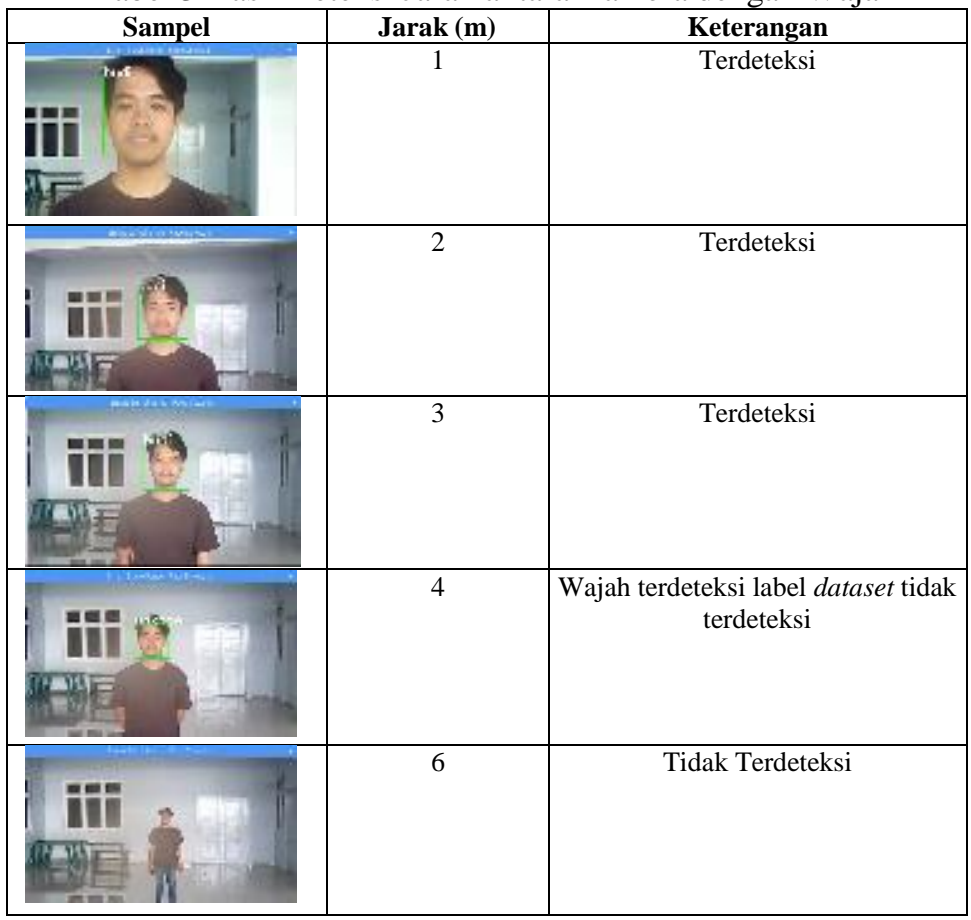

Pengujian kedua deteksi jumlah wajah dilakukan untuk mengetahui jumlah wajah terdeteksi. Pengujian dilakukan dengan sampel 1 sampai 5 wajah.

Tabel 4 Hasil dari Pengujian Jumlah Wajah Terdeteksi

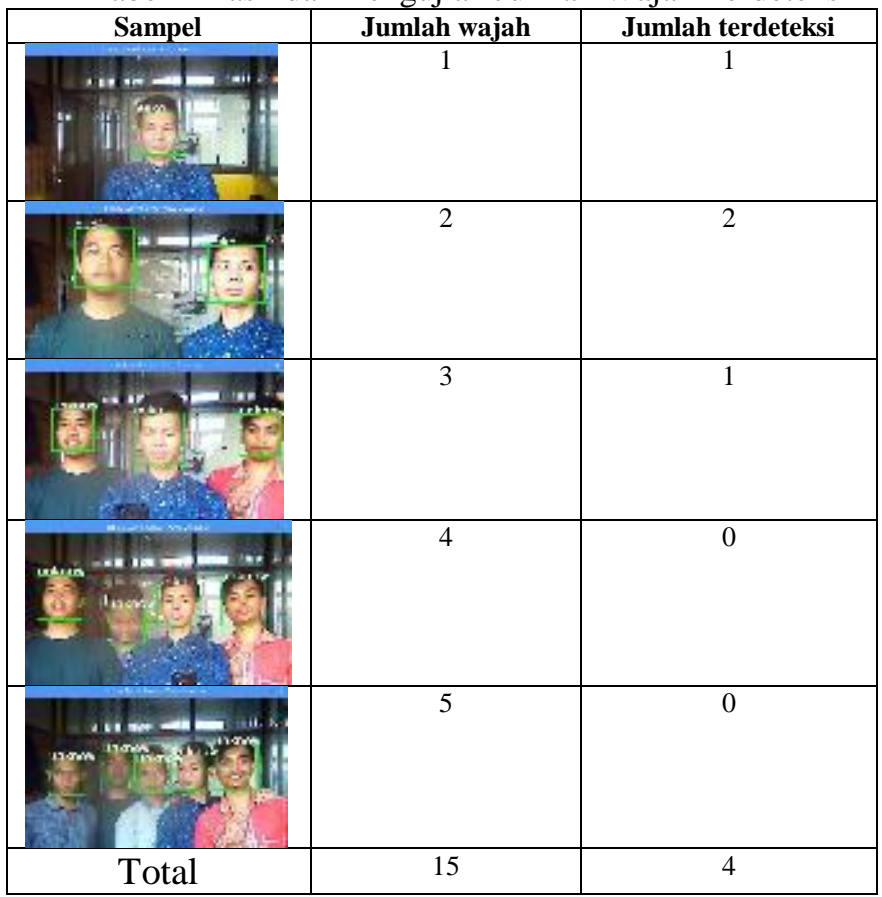




\section{Pembahasan}

Pengujian dilakukan pada siang hari dalam keadaan cuaca cerah dengan ketinggian kamera $150 \mathrm{~cm}$. pengujian ini bertujuan untuk mengetahui jarak pendeteksian dan akurasi sistem. pegambilan video dilakukan secara realtime.

Untuk mengetahui tingkat akurasi sistem yang telah diracang untuk mendeteksi jumlah manusia dan pengenalan wajah, menggunakan persamaan seperti di bawah ini;

$$
\text { Akurasi }=\frac{\text { Jumlah data benar }}{\text { jumlah keseluruhan data }}
$$

Jumlah data benar $=$ Jumlah obyek terdeteksi dengan benar Keseluruhan data $=$ Jumlah total sampel pengujian

\section{Deteksi Jumlah Manusia}

Hasil deteksi manusia dengan jarak 2 meter sampai dengan 13 meter. Pada jarak $2-3.5$ meter sistem masih belum mampu mendeteksi adanya obyek manusia. Sedangkan pada jarak 5 meter sampai 11 meter sistem mampu mendeteksi obyek manusia sehingga muncul garis kotak pada obyek yang terdeteksi dan muncul keterangan " jumlah orang $=1$ " pada sudut atas sebelah kiri pada output video. pada jarak 13 meter sistem sudah tidak mampu mendeteksi adanya obyek mausia sehingga muncul keterangan "jumlah orang $=0$ " pada output video. Hal ini terjadi karena ukuran piksel obyek terlalu besar apabila berjarak kurang dari $3.5 \mathrm{~m}$. Dan terlalu kecil apabila berjarak lebih dari 11 meter.

Pada pengujian ini dilakukan sebanyak 55 sampel. Pengujian dimulai dari satu orang sampai 10 orang. pada pengujian ini didapatkan hasil terdeteksi 51 dan hasil tidak terdeteksi 4 , hal ini disebabkan letak posisi obyek manusia secara acak sehingga ada obyek manusia yang terdeteksi oleh sistem hanya satu obyek untuk mencari nilai akurasi menggunakan persamaan (6)

$$
\begin{aligned}
\text { Akurasi } & =\frac{51}{55} \times 100 \% \\
& =92,72 \%
\end{aligned}
$$

Dari hasil perhitungan menunjukan tingkat akurasi deteksi jumlah manusia sebesar 92,72\%

\section{Deteksi Pengenalan Wajah}

Dilakukan 2 percobaan yang berbeda percobaan yang pertama dilakukan dengan satu wajah denga jarak yang bervariasi untuk mengetahui jarak minimum dan maksimum. untuk jarak $1-3$ meter obyek wajah terdeteksi dan sistem juga mampu mengenali label nama sesuai dengan dataset yang sudah disimpan. Pada jarak 4 meter sistem mampu mendeteksi adanya wajah tetapi sistem tidak mampu mendeteksi label nama dataset sehingga muncul keterangan "unknow" pada label wajah yang terdeteksi. Selanjutnya pada jarak 5 meter sistem tidak mampu mendeteksi adanya wajah dan juga label nama sehingga tidak muncul keterangn apapun pada wajah obyek manusia. Penyebab tidak terdeteksinya wajah pada jarak lebih dari 3 meter dikarenakan ukuran piksel terlalu kecil sehingga sistem tidak mampu mendeteksi sesuai dengan dataset.

Adapun pengujian lain yang dilakukan adalah untuk mengetahui jarak antara manusia yang akan dideteksi menunjukan bahwa semakain jauh obyek dari kamera dan semakin dekat antara dua obyek yang bersebelahan maka akan sulit untuk mendeteksi kedua obyek sehingga sistem hanya mampu mendeteksi satu obyek manusia saja.

Pada pengujian ini dilakukan dengan mendeteksi wajah berurutan dari satu wajah sampai 5 wajah. jumlah terdeteksi dari keseluruhan pengujian adalah 4 wajah sedangkan jumlah salah atau tidak terdeteksi sesuai dengan label dataset adalah 11 wajah. Akurasi pengenalan wajah yang kurang baik ini di sebabkan karena keterbatasan pada perangkat raspberry sehingga saat mendeteksi wajah lebih dari 2 maka video akan mengalamai delay. Sehingga menghambat 
proses pengenalan wajah tetapi sistem mampu mendeteksi keseluruhan wajah baik dari satu wajah sampai dengan 5 wajah secara bersamaan. Untuk mencari nilai akurasi menggunakan persamaan (6)

a. Akurasi label sesuai dataset

$$
\begin{aligned}
\text { Akurasi } & =\frac{4}{15} \times 100 \% \\
& =26,67 \%
\end{aligned}
$$

Dari hasil perhitungan menunjukan tingkat akurasi deteksi pengenalan wajah sesuai dengan dataset memiliki akurasi sebesar $26,67 \%$

b. Akurasi pendeteksian wajah

$$
\begin{aligned}
\text { Akurasi } & =\frac{15}{15} \times 100 \% \\
& =100 \%
\end{aligned}
$$
$100 \%$

Pendeteksian adanya wajah tidak dengan label nama. Menunjukan tingkat akurasi sebesar

\section{KESIMPULAN DAN SARAN}

Berdasarkan hasil penelitian dan pembahasan, yang dilakukan mulai dari tahap perancangan hingga pengujian terhadap deteksi jumlah dan pengenalan wajah manusia menggunakan metode Histogram Of Oriented Gradient dan Viola Jones secara real time berbasis raspberry pi maka kesimpulan yang dapat diambil dari penelitian ini adalah sebagai berikut :

1. Pada deteksi jumlah manusia memiliki keberhasilan pendeteksian pada jarak minimal 5 meter dan jarak maksimal adalah 11 meter.

2. Hasil pengujian menunjukkan tingkat akurasi mencapai $92,72 \%$ dan nilai eror sebesar 7,28 $\%$ dalam mengenali jumlah manusia.

3. Pada pengujian pengenalan wajah sistem mampu mendeteksi pada jarak $1-3$ meter

4. Hasil pengujian menunjukkan tingkat akurasi mencapai $26,67 \%$ dan memiliki nilai error sebesar $73,33 \%$ dalam mengenali wajah manusia.

5. Pada pendeteksian adanya wajah didapatkan akurasi sebesar $100 \%$ dan error $0 \%$.

6. Raspberry pi 3 model B untuk mendeteksi pengenalan wajah jika lebih dari dua wajah secara bersamaan maka proses kurang mumpuni sehinga mengalami delay pada deteksi pengenalan wajah

7. Proses yang lebih sulit adalah mengetahui obyek wajah tersebut mirip dengan obyek yang mana yang sudah ada dari database.

Dari hasil penelitian yang dilakukan, untuk pengembangan berikutnya, disarankan untuk menggunakan Raspberry Pi model terbaru dengan kapasitas $R A M 4$ GB untuk mempercepat proses identifikasi dan juga menggunakan metode Convolutional Neural Network untuk hasil yang lebih maksimal. Selain itu diharapkan penelitian ini dapat dijadikan acuan bagi penelitian selanjutnya agar hasil dari penelitian ini dapat dibandingkan dengan pendekatan yang lain.

\section{DAFTAR PUSTAKA}

[1] M. Muchsin, F. Rofii, dan I. Jaenuri, "Rancang Bangun Prototype Monitoring Kemanan Rumah Berbasis Closed Circuit Television (CCTV) Dengan Detektor Gerak," Widya Tek., Vol. 22, No. 1, 2014.

[2] M. H. B. Pratama, A. Hidayatno, dan A. A. Zahra, "Aplikasi Deteksi Gerak Pada Kamera Keamanan Menggunakan Metode Background Subtraction Dengan Algoritma Gaussian Mixture Model," Transient, vol. 6, no. 2, hlm. 246-253, 2017.

[3] M. Kachouane, S. Sahki, M. Lakrouf, dan N. Ouadah, "HOG based fast human detection," dalam 2012 24th International Conference on Microelectronics (ICM), 2012, hlm. 1-4. 
[4] C. Cosma, R. Brehar, dan S. Nedevschi, "Pedestrians detection using a cascade of LBP and HOG classifiers," dalam Intelligent Computer Communication and Processing (ICCP), 2013 IEEE International Conference on, 2013, hlm. 69-75.

[5] R. Y. Endra, A. Cucus, F. N. Afandi, dan M. B. Syahputra, "Deteksi Objek Menggunakan Histogram Of Oriented Gradient (HOG) Untuk Model Smart Room,” Explore, vol. 9, no. 2, 2018.

[6] F. Hermawanto dan R. S. Sinukun, "Deteksi Obyek Manusia Pada Sistem Keamanan Gedung Menggunakan Webcam,” J. Technopreneur JTech, vol. 4, no. 2, hlm. 127-130, 2016.

[7] A. H. Triatmoko, S. H. Pramono, dan H. S. Dachlan, "Penggunaan Metode Viola-Jones dan Algoritma Eigen Eyes dalam Sistem Kehadiran Pegawai," J. EECCIS, vol. 8, no. 1, hlm. 41-46, 2014.

[8] P. Viola dan M. J. Jones, "Robust real-time face detection," Int. J. Comput. Vis., vol. 57, no. 2, hlm. 137-154, 2004.

[9] P. Viola dan M. Jones, "Rapid object detection using a boosted cascade of simple features," dalam Computer Vision and Pattern Recognition, 2001. CVPR 2001. Proceedings of the 2001 IEEE Computer Society Conference on, 2001, vol. 1, hlm. I-I.

[10] M. Mahmudi, K. Kusrini, dan others, "Implementasi Metode Viola Jones Untuk Mendeteksi Wajah Manusia,” J. Inf., vol. 5, no. 1, hlm. 54-60, 2019. 